\title{
Identifying the chemical structure and degradation processes in the bituminous mortar of Achaemenid monument of Tall-e- Ajori in Persepolis
}

\author{
S. YOUSEFNEJAD* \\ Ph.D. Candidate, Art University of Tehran, IRAN
}

\begin{abstract}
In this paper the bituminous water proof mortar, which has been used between the bricks in the Achaemenes monument of Tall-e-Ajori in Persepolis, has been analyzed by different instrumental chemical analysis methods, such as Fourier transform infrared spectroscopy (FTIR), X ray diffraction (XRD and X ray florescence spectroscopies (XRF). Moreover, due to identifying the chemical structure and explanation the degradation processes during thousand years of remaining in burial environment, the classical extraction by organic solvents and optical microscopy studies were also done. According to classical extraction test results, the physical state of the bituminous water proof mortar is a duple mixture that include organic and inorganic parts, where the characteristic of the material is actually a natural asphalt. The organic part of this bituminous mixture was analyzed by FT-IR method for identifying the main organic functional groups such as alkanes and aromatic molecules, XRD analysis determined the presence of inorganic phases such as Calcite, Anhydrite, Feldespar (Ca), Quartz and Dolomite, and the result of XRF analysis determined weight percent of $\mathrm{CaO}, \mathrm{SO}_{3}, \mathrm{SiO}_{2}, \mathrm{Al}_{2} \mathrm{O}_{3}, \mathrm{Fe}_{2} \mathrm{O}_{3}$ and $\mathrm{MgO}$. The degradation processes during thousands of years in the burial environment have developed the age-hardening reactions which decrease the saturated molecules concentration such as oils and resins in bituminous mixture, and caused the enhanced fragility and brittleness in the structure of the material. So, the results obtained clarifies the importance of conservation programming and climate controlling for optimum preserving of the bituminous mixture mortars in the Achaemenes monument remains of Tall-e-Ajori in persepolis.
\end{abstract} Keywords: Bitumanius mortar, Achaemenid, Tall-e-Ajori, XRF, XRD, FTIR.

* - Corresponding author: syousefnezhad@yahoo.com. 


\section{شناسايى ساختار و فرآيندهاى فرسايث ملات قير بدكار رفته در آجرهاى يادمان هخامنشى تل آجرى در يارسه}

سودابه يوسفنزاد*

دانشجوى دكترى مرمت آثار تاريخى - فرهنگى، دانشكاه هنر تهران.

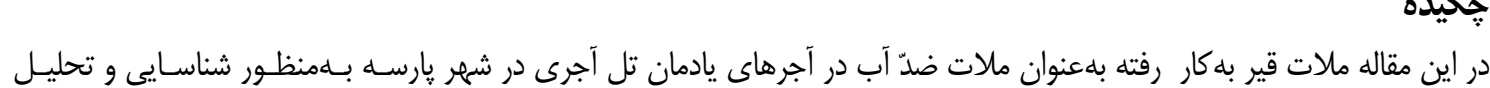

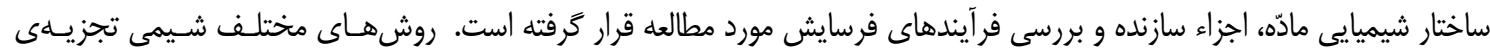

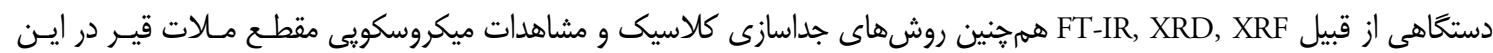

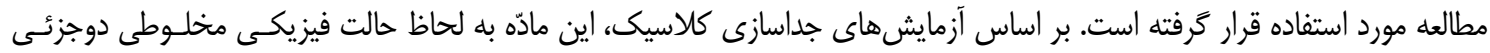

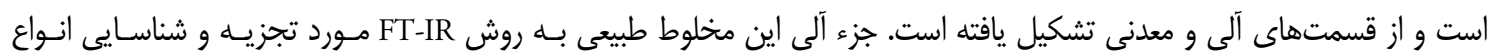

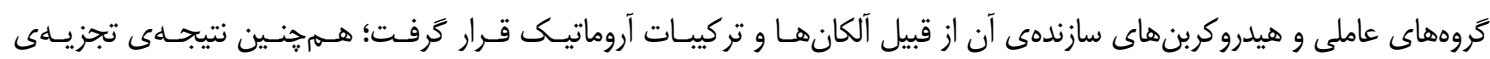

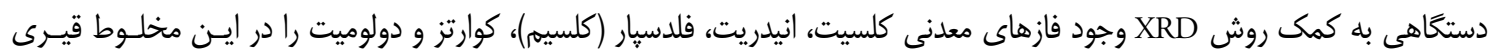

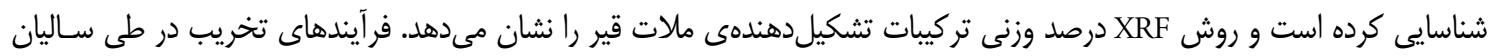

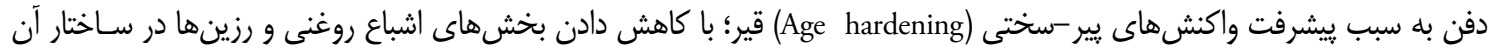

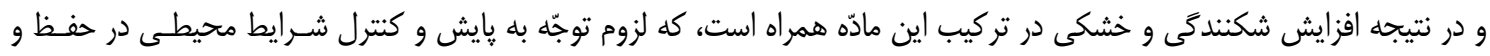

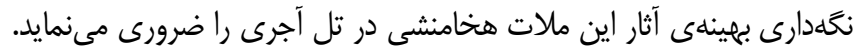

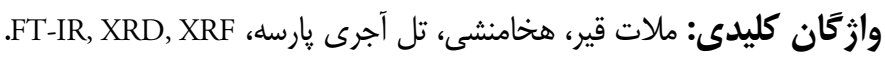

" نويسنده مسئول: مكاتبات: تهران، خ حافظ، خ سخايى، دانشكاه هنر تهران، كروه دكترى مرمت اشياء و آثار تاريخى - فرهنكى.

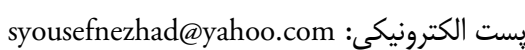
C) حق نشر متعلق به نويسنده(كان) است و نويسنده تحت مجوز Creative Commons Attribution License به مجله اجازه مى دهد مقاله خابٍ شده را با ديخران به اشتراك بحذارد منوط بر اينكه حقوق مؤلف اثر حفظ و به به انتشار اوليه مقاله در اين مجله اشاره شود. 
يافت. جين خوردخى هاى زاخرس از سويى، مقادير وسـيعى

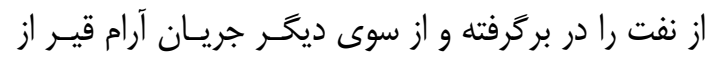

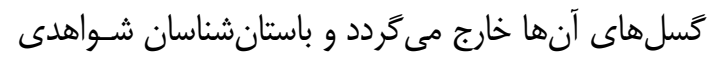

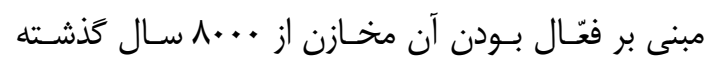

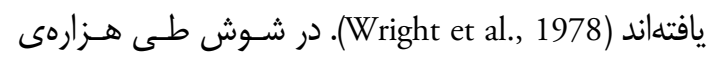

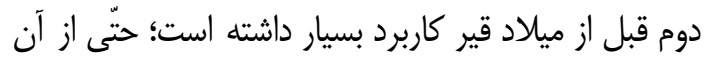

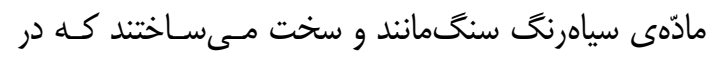

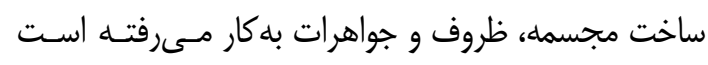

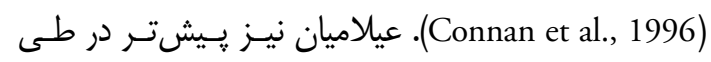

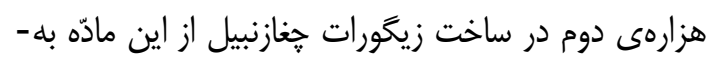

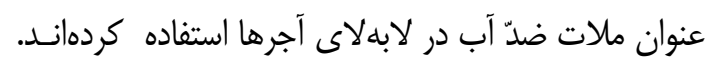

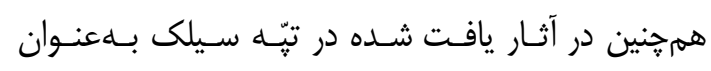

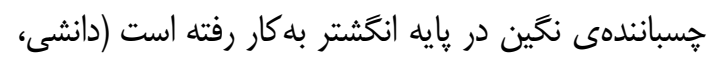

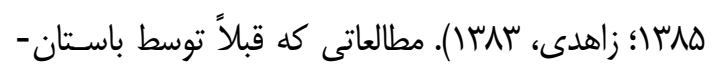

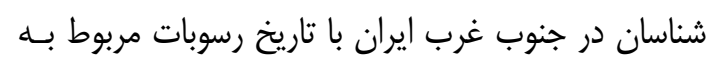

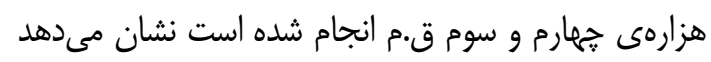
كه در ساخت ملات قير از مواد خام مخازن محلّى استفاده

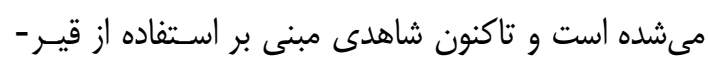

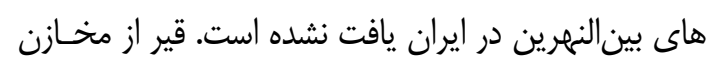

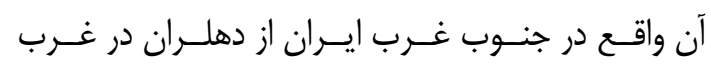

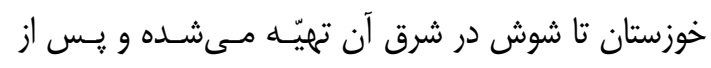

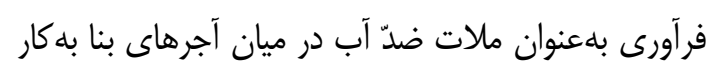

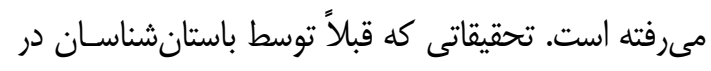

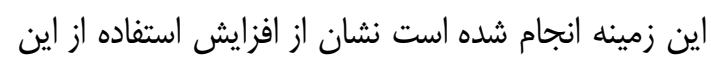

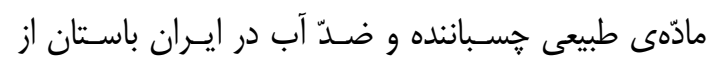

حدود هزارهى سوم ق.م دارد (Wright et al., 1978). يادمان تل آجرى در كاوشهاى بارد باستانشناسى سـال

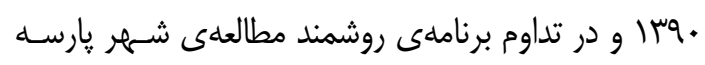

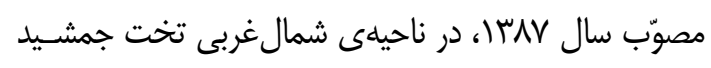

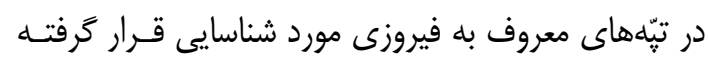

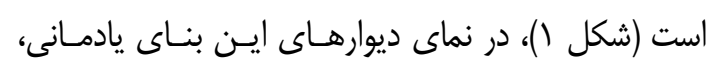

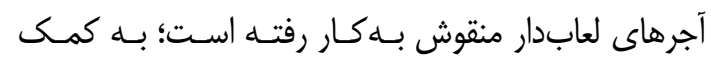

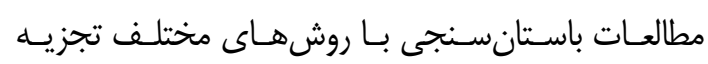

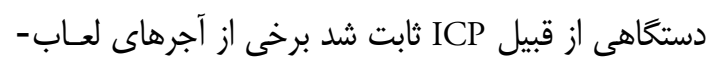

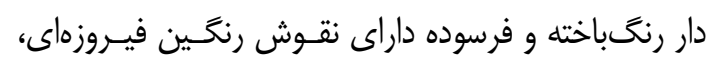

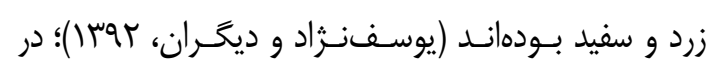

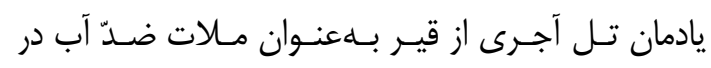

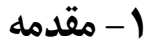
در دوران ييش از تاريخ و دوران تـاريخى اسـتفاده از قيـر

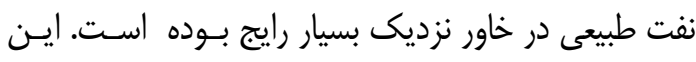

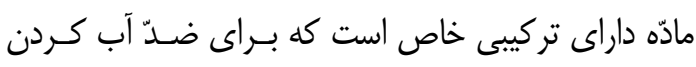

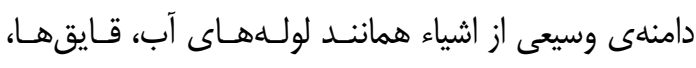

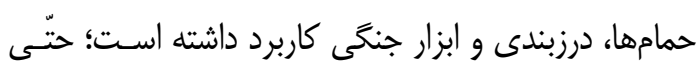

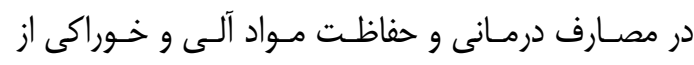

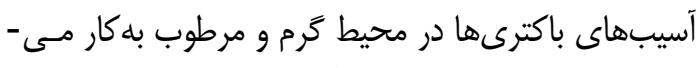

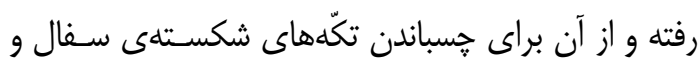

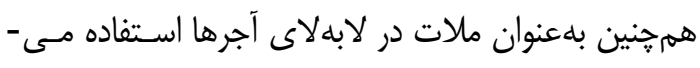

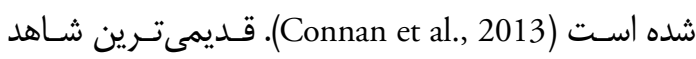

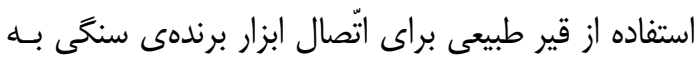

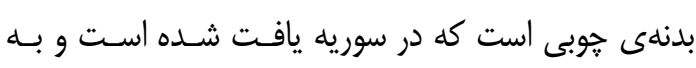

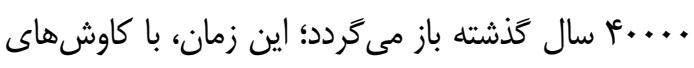

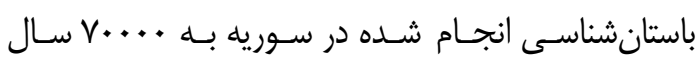

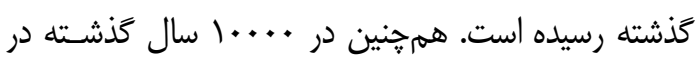

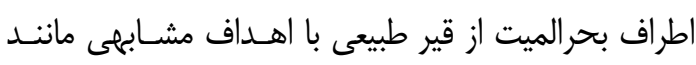

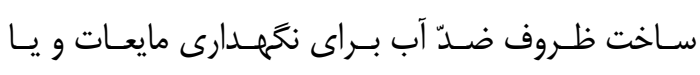

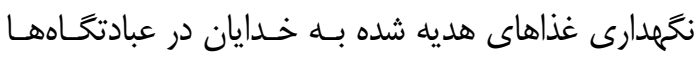

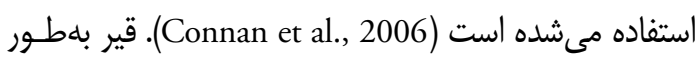

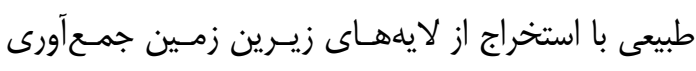

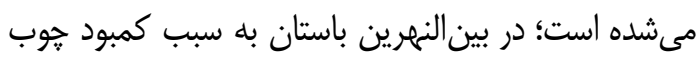

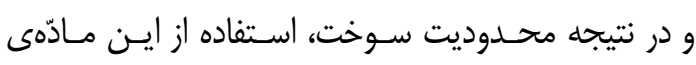

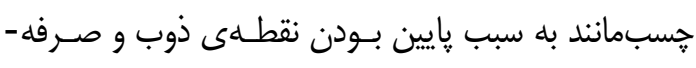
جويى در مصرف سوخت در ميان مردم رواج بسيار داشت.

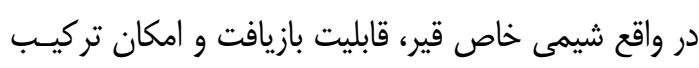

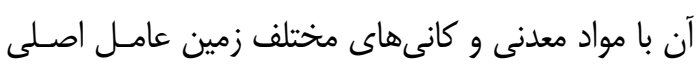

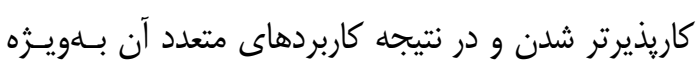

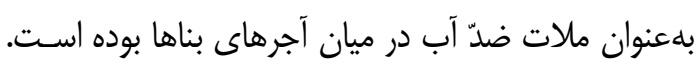
قير با استخراج در مقياس صنعتى توسط مردم بين النهرين

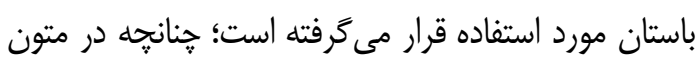

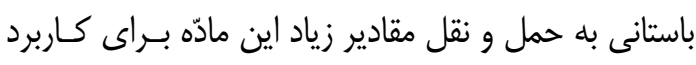

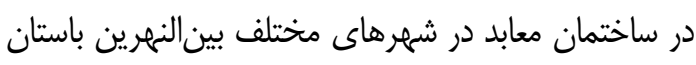

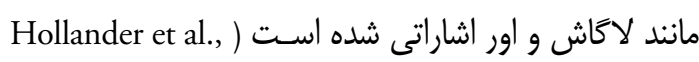

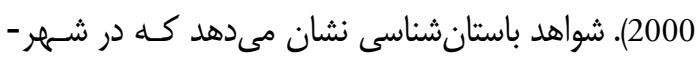

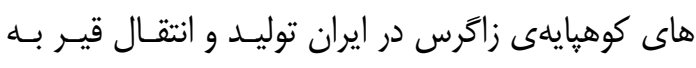

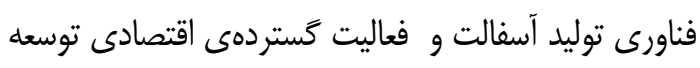

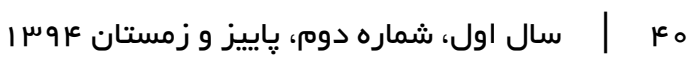




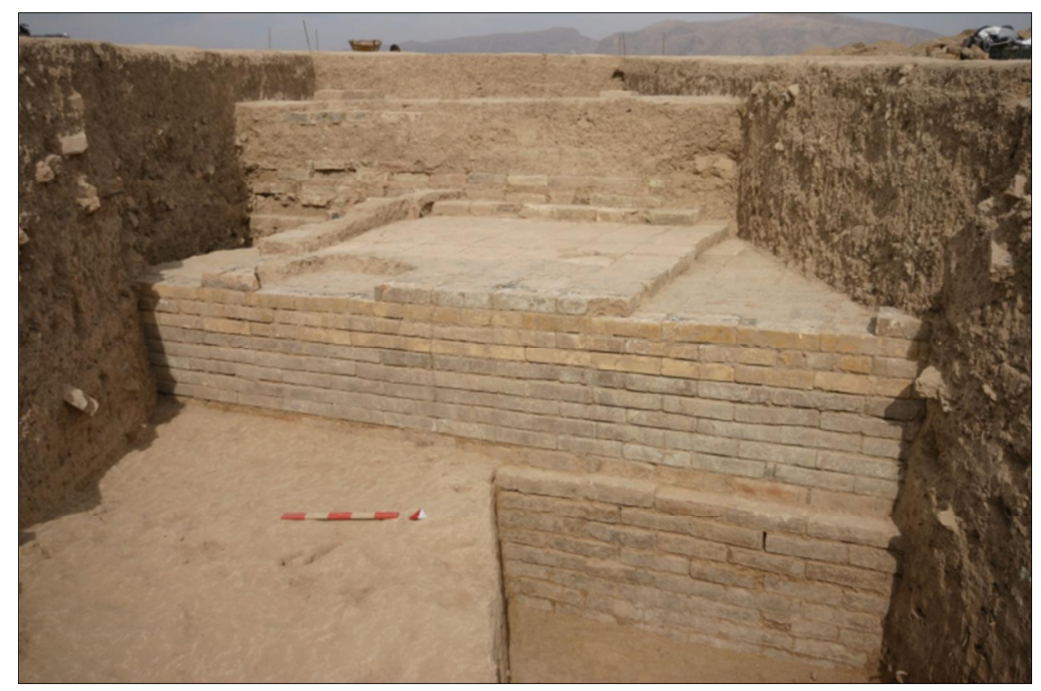

شكل (: بخشى از يادمان تل آجرى (عسكرى و ديكران، •وَ")

نمونهاى نواحى مختلف انجام شده است (1978)

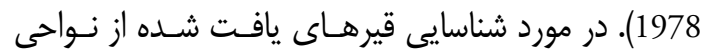

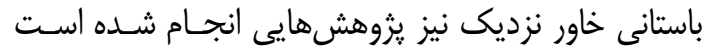
كه در موردى يّس از اشاره به اهميّت و كاربرد ايـن مـادّه

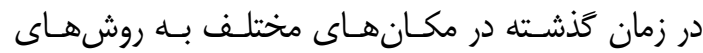

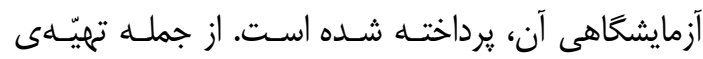

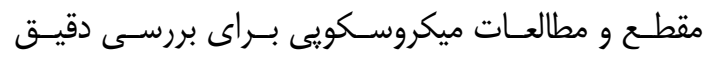
وضعيت ظاهرى نمونه، كاربرد روشهاى جداسازى توسط مطات

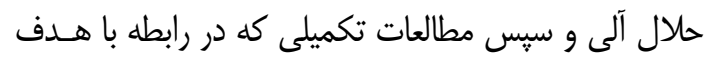

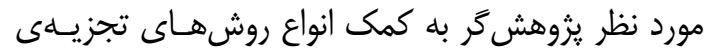

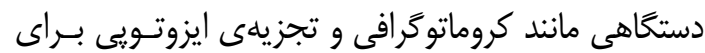

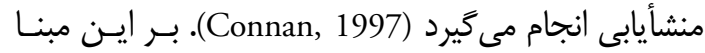

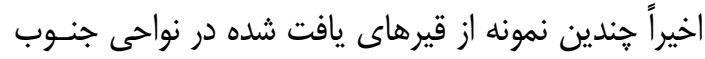
شرقى تركيه اطراف رودخانهى دجله به روشهاى نهاى مـذكور

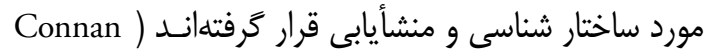

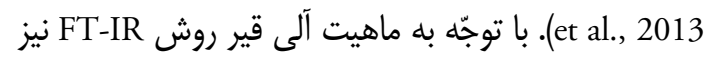
در موارد متعددى بـراى شناسـايى حَروههـاى عـاملى در

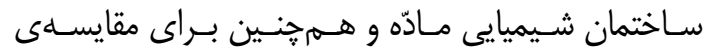

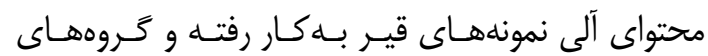
مختلف تركيبات هيدروكربنى مانند آلكـانهـا و تركيبـات

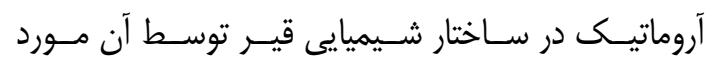

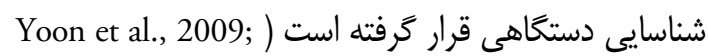

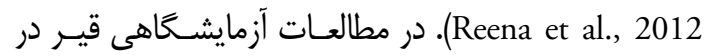

لابهلاى آجرها استفاده شده است (عسـحرى و ديخـران، •وسا). هدف از انجام اين يزوهش شناسـايى و تحليـل ساختار فيزيكى و شيميايى اين مادّه به كمك روشهاى آناي

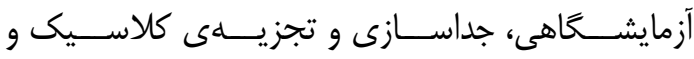
دستخاهى، سبس بررسى و تشريح فرآيندهاى فرسـايش

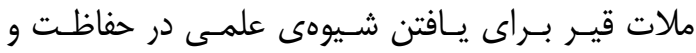
نكَهدارى آنها است.

\section{r- بيشينه تحقيق}

نقطهى مشـترك در مطالعاتى كـه يـيشتر در زمينـهى

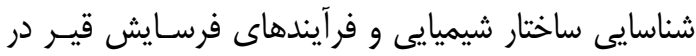

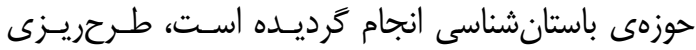

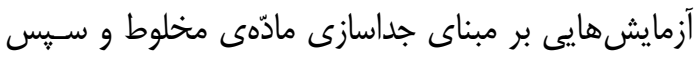

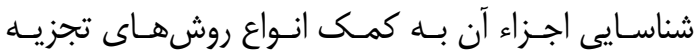

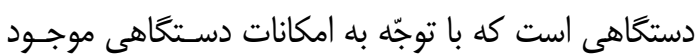

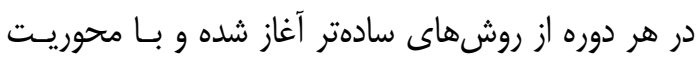

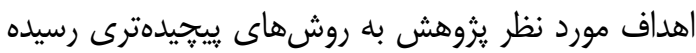

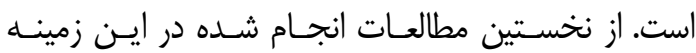
يزوهشى در مورد نمونه قيرهاى نواحى جنوب غربى ايران به كمك روش جداسازى ساده توسط حلال آلى تولوئن و

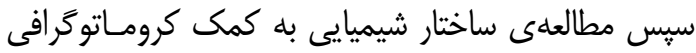

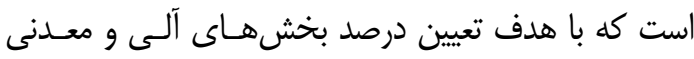

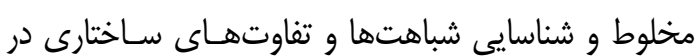

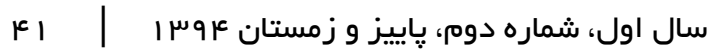


قرار مسى كيرنــ (Wong et al., 2015). هيـدروكربنهـاى

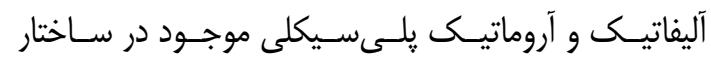

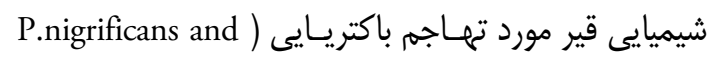
(P.putrefaciens bacteria

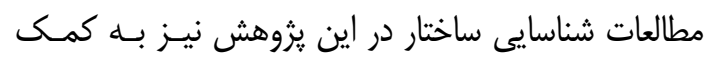
روش FT-IR انجام شده است.

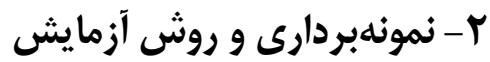

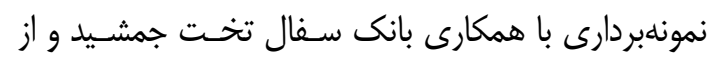

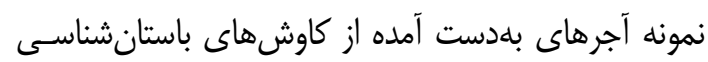

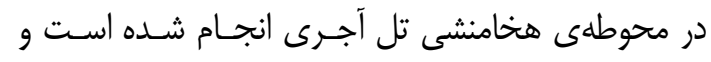

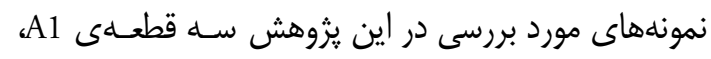

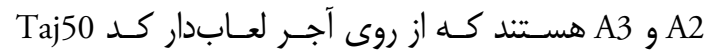

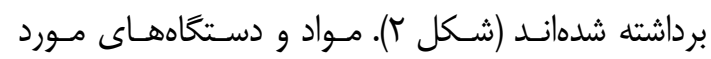

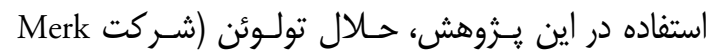
آلمان)، ميكروسكوب نـورى (Olympus CX21)، دسـتخاه

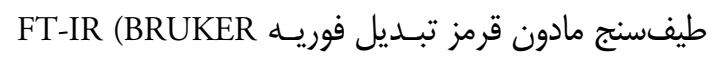

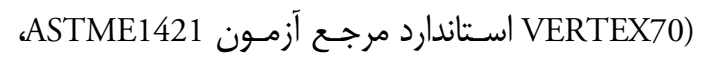

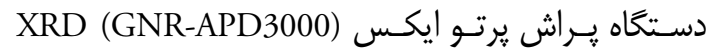
استاندارد مرجع آزمون

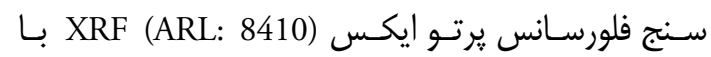
استاندارد مرجع آزمون ASTM E1621-13 است. براى بررسى وضعيت سطح با تهيّــى مقطع(هاديـان

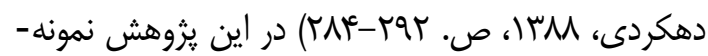
هاى ملات قير، ابتــا توسـط ميكروسـكوب نـورى مـورد

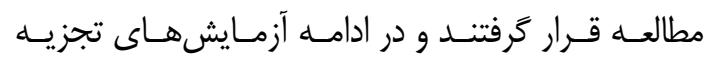
كلاسـيك و جداسـازى شـامل جداسـازى بخـش آلـ آلـى از

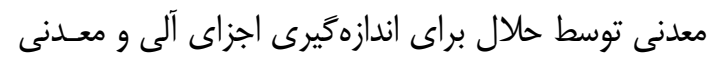

مـــوارد متعــدد بــراى جداســازى بخــش آلـى و ذرات

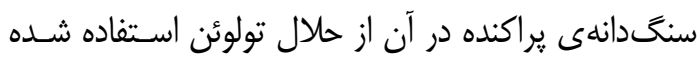

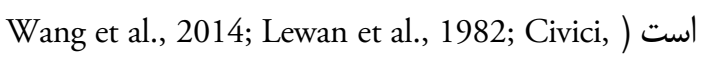
1995). با توجّه به فرسوده بودن نمونههـاى مـاتلات قيـر،

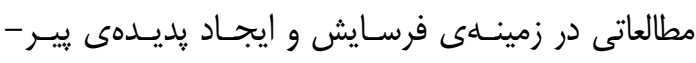

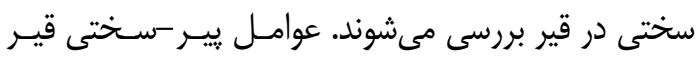

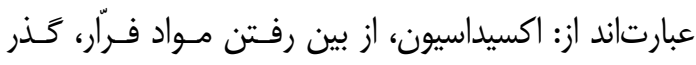
زمان كه سبب تغييـر سـاختار شـيميايى قيـر مسىشـود و

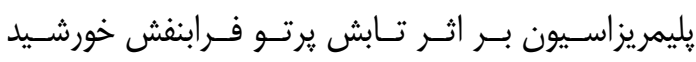

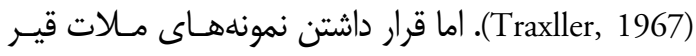
مورد مطالعه در اين يزوهش در محيط دفـن در مجـاورت

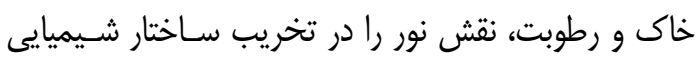

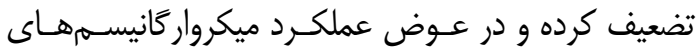

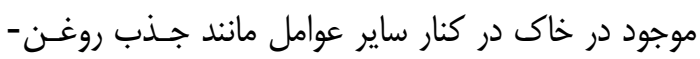
هاى موجود در قير توسط مصالح در طى زمان، قابل تأمّل

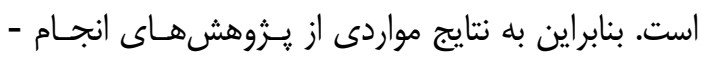
كرفته در اين زمينه نيز اشارهاى مىشود.

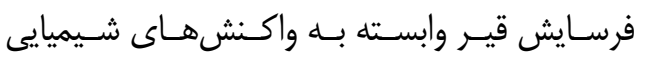

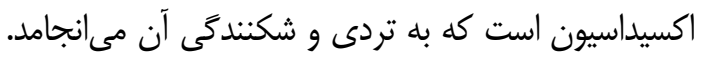
در اثر فر آيندهاى فرسايش تركيبات سولفوكسيد و كتون و و

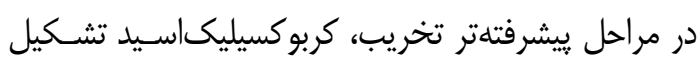

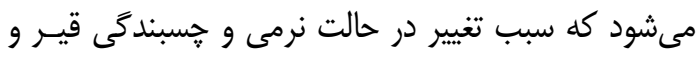

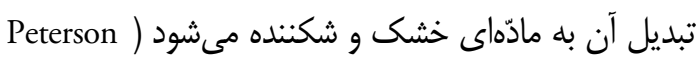

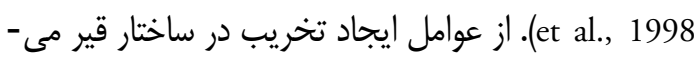

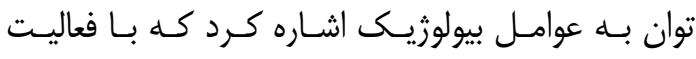

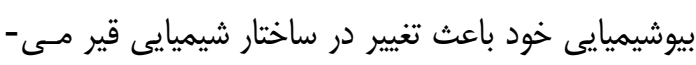

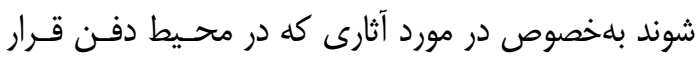
داشتهاند، مورد تخريب عواملى مانند باكترىها و قـارجهـا
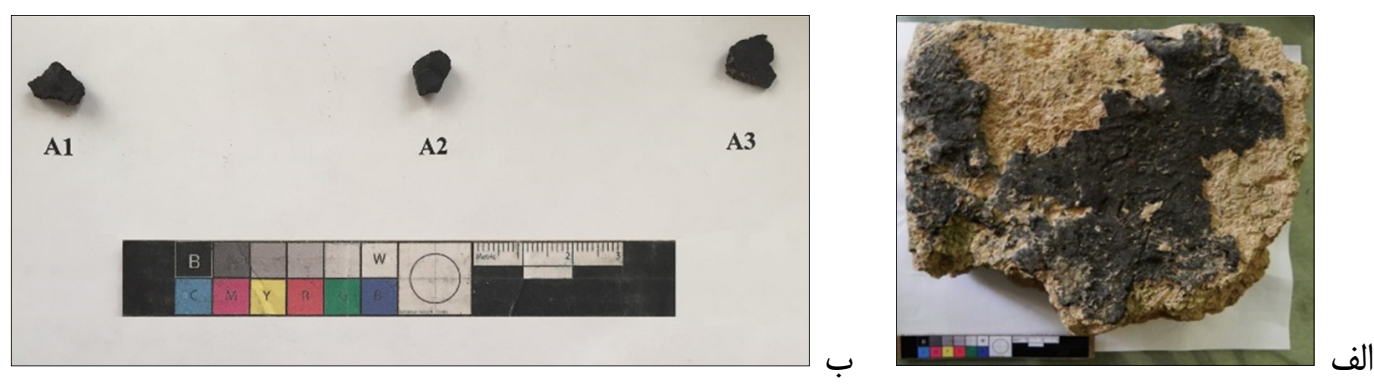

شكل ז: الف) نمونه آجر داراى ملات قير كه نمونهها از روى آن برداشته شدهاند

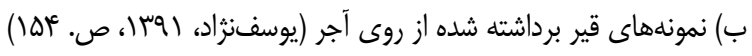


در زمينهى قير يراكندهاند بنـابراين بـراى جداسـازى و در

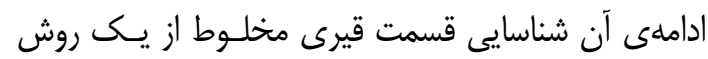

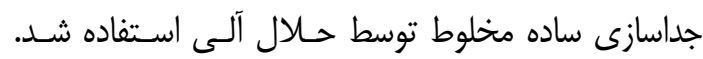
بخش آلى مخلوط در تولوئن حل شد و رسوبات نـامحلول

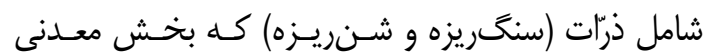
مخلوط را تشكيل مىدهند بلصورت نامحلول باقى ماندند؛

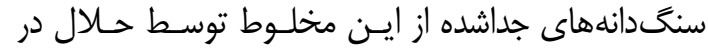

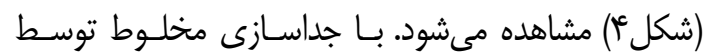

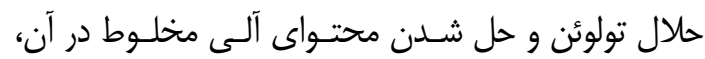

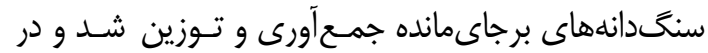

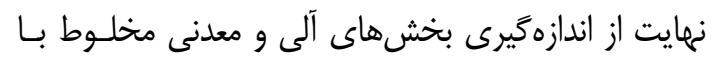

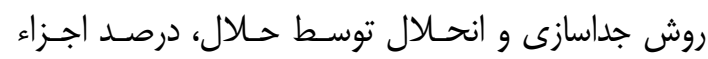

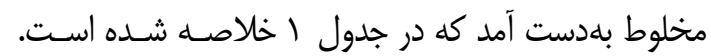

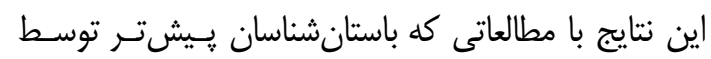

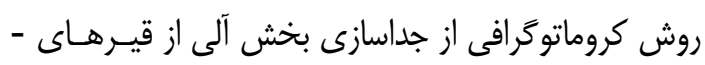

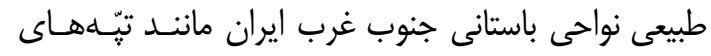

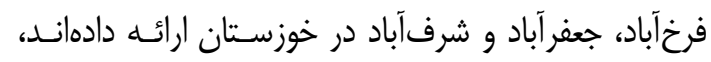

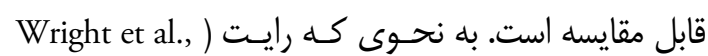

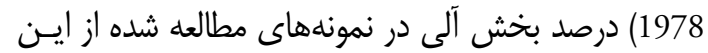

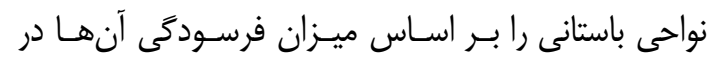

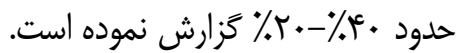
بررسى نتايج اندازگيرى شده در اين تحقيق نشان

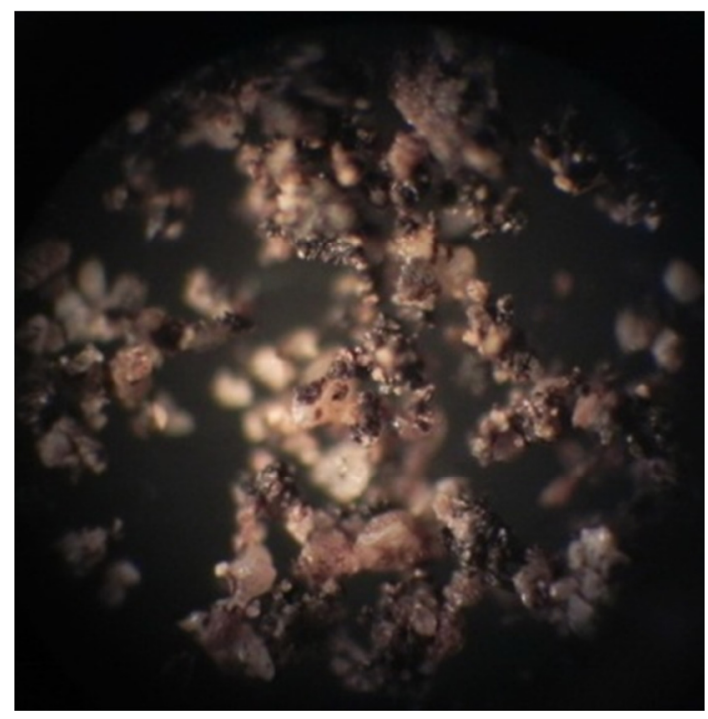

شكل أ: تصوير ميكروسكويى بزر كنمايى ..1 ذرات جدا شده از مخلوط توسط حلال تولوئن

$\kappa \mu$ سال اول، شماره دوم، ياييز و زمستان ع ع |

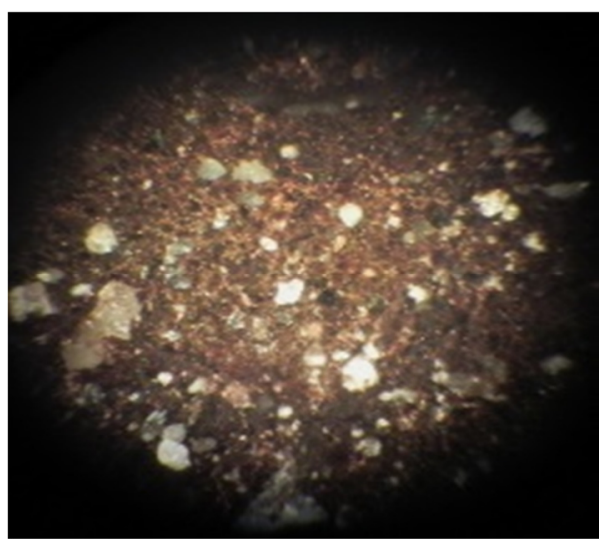

شكل سّ: تصوير ميكروسكويى مقطع تهيه شده از نمونهى ملات قير X...

انجام شد. روشهــاى شـيمى تجزيـهـ دسـتخاهى از قبيـل

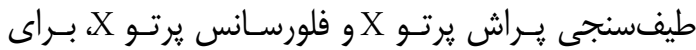

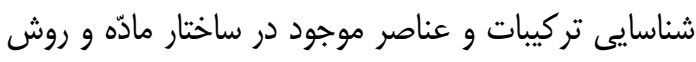

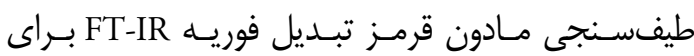
شناسايى گروههاى عاملى سازندهى آن بلهكار رفته است.

\section{ץ- مشاهدات ميكروسكويى}

بلمنظور مشاهدهى دقيق وضعيت سطح و ساختار ظاهرى

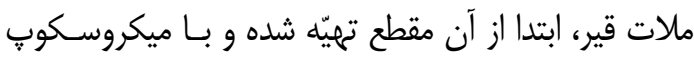

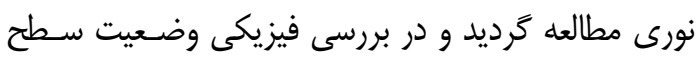

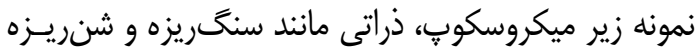

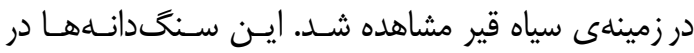

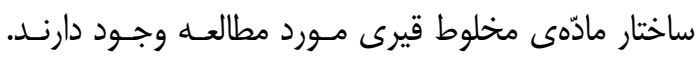
بدين ترتيب بر مبناى مشـاهدات ميكروسكويكى، مـادّهى

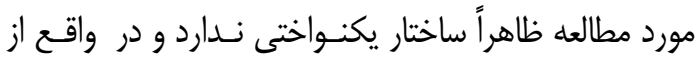

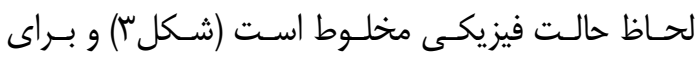

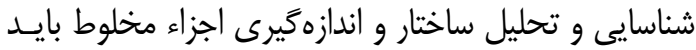

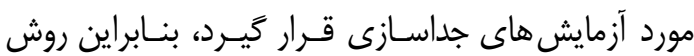

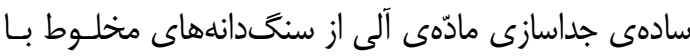
حلال آلى براى اين منظور بهكار مىرود.

\section{ح أ - آزمايش هاى شيمى كلاسيك براى

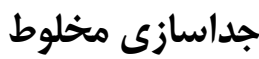

با توجّه به مطالعـات ميكروسكويى از مقطع تهيّــهـ شـده

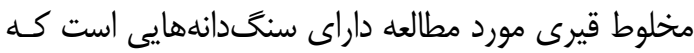




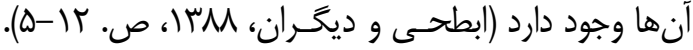

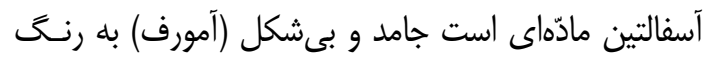

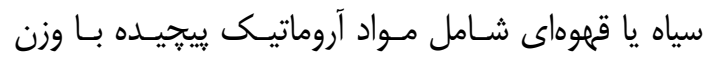

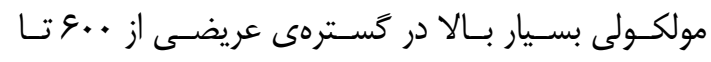

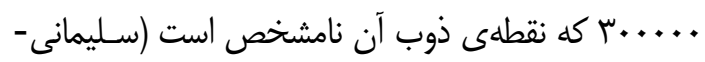

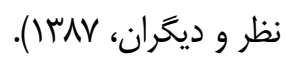

\section{ه- آزمايش طيفسنجى مادون قرمز تبديل}

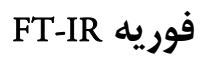

تجزيه و شناسايى گروههاى عـاملى موجـود در سـاختمان

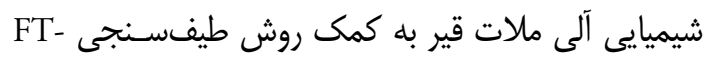

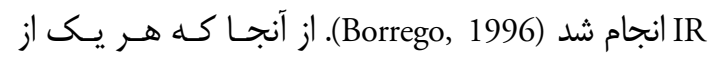

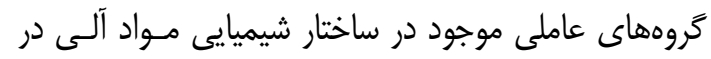

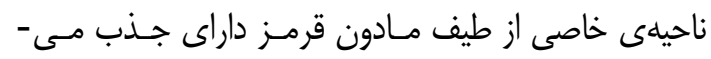

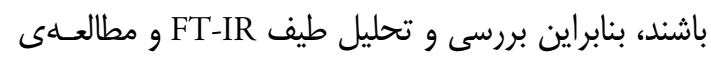

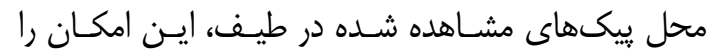

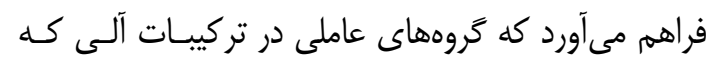

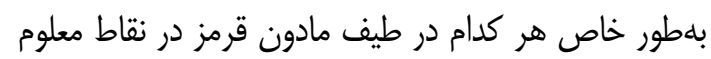

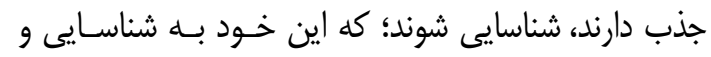

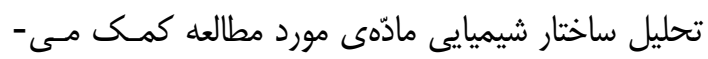
كند. بدين ترتيب با توجّه به طيف (شكل هام)، مادّى مورد

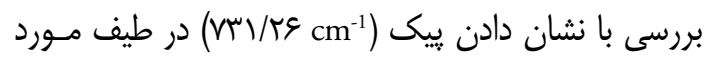
مطالعه داراى تركيبات آلكان با زنجيرهى بلند هيدروكربنى بلى بران مانند روغنهاى معدنى است. هــمجنــين داراى تركيبـات
جدول ا: درصد اجزاء معدنى و آلى اندازميّي شده با روش

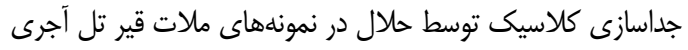

\begin{tabular}{|c|c|c|c|}
\hline نمونه & gون نمونه g & بخش آلى Wt\% & بخش معدنى Wt\% \\
\hline A1 &.$/ I V$ & $r q / 4$ & $v \cdot 19$ \\
\hline $\mathrm{A} 2$ &.$/ 14$ & $41 / 99$ & سM/ND \\
\hline A3 &.$/ 19$ & MI/Ta & SN/VD \\
\hline
\end{tabular}

مى دهد كه در اين مخلوط بـيش از نصـف نمونسه بخـش

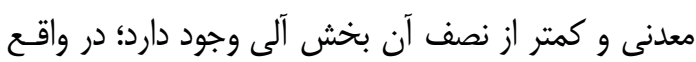
مادّى مورد مطالعه مخلوطى است از ذرات ســـــدانـه و قير كه بلهور طبيعى در مخازن نفت تشـكيل مسى مـردد.

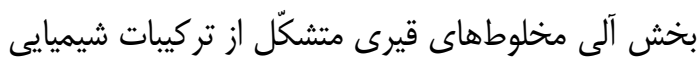
ييجيديده، مولكولهاى هيدروكربن طبيعى با مقدار جزئسى از تركيبات هتروسيكلى و گروههاى عاملى است كه در ايـن

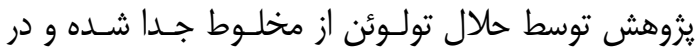

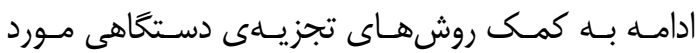

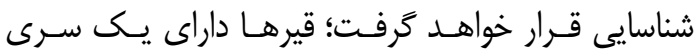

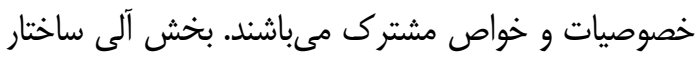

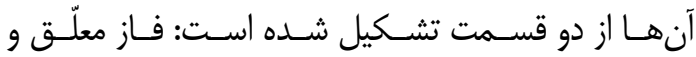

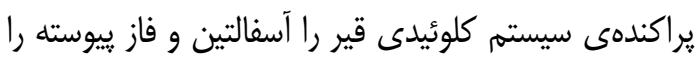

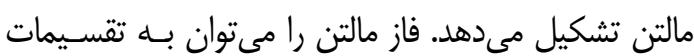

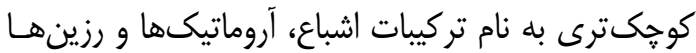
طبقهبندى كرد. البته لازم به ذكر است كه ايـن حـروههـا

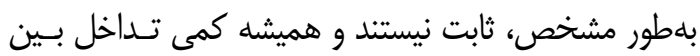

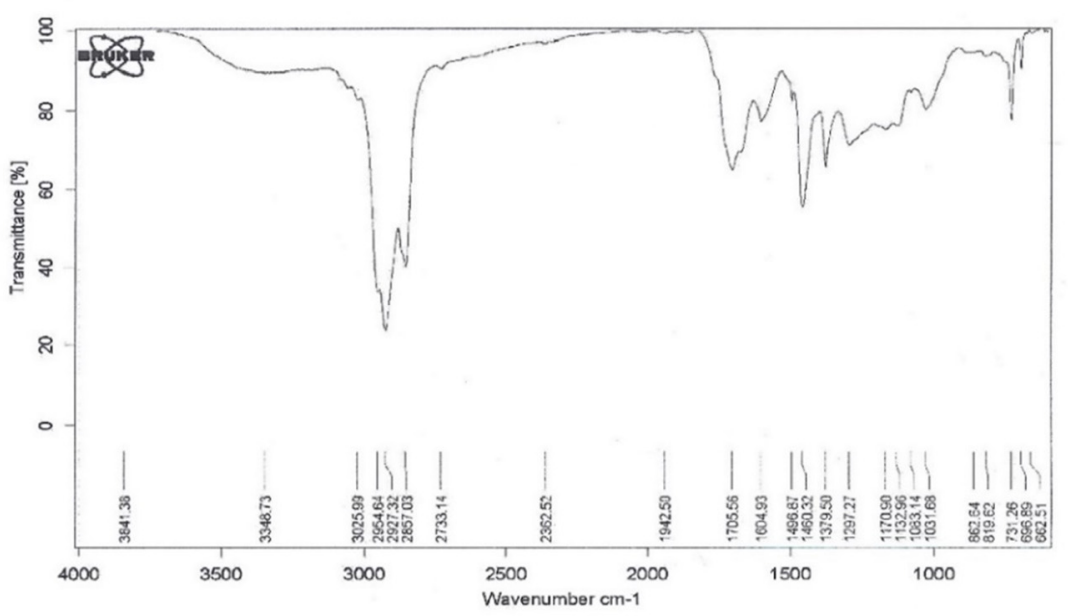

شكل ه: طيف FT-IR نمونه ملات قير تل آجرى 


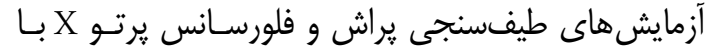
شناسايى تركيبات و فازهاى معلنى مانند كلسيت، فلدسيار (كلسيه)، كوارتز و دولوميت و وجود تر كيبات كنات كلسيه، آهن، منيزيم و سيلسيم حضور كوارتز و ذرات رسى رادر بخـش ونس

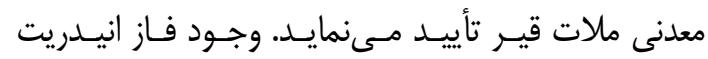

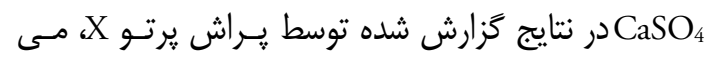

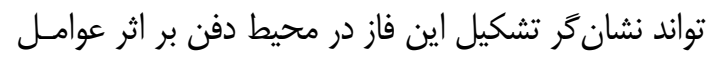
فرساينده از قبيل واكنش سولفاتها با كربنـات كلسـيمه در حضور رطوبت باشد. همجنين عملكرد ميكروار كانيسمهاى موجود در خاك از جمله باكترىهاى اكسيدكنندهى توخرّد نيـز مسىتوانتــد در (S.O.B (sulfur oxidizing bacteria)) ايجاد تركيبات سولفات در ساختمان شـيميايى مـادّه مـؤثر بوده باشند (May, 2006, p. 220-226).

\section{- بر رسى و تحليل فر آيندهاى فرسايثى}

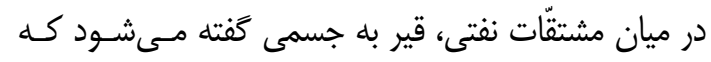

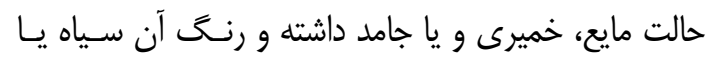

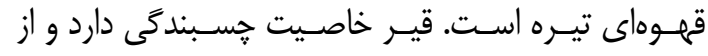

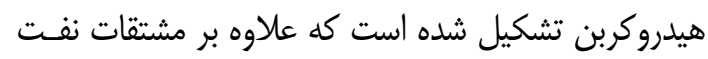

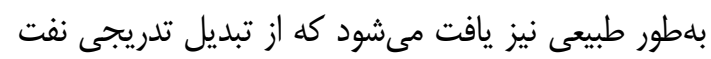

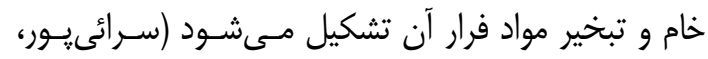
جWW

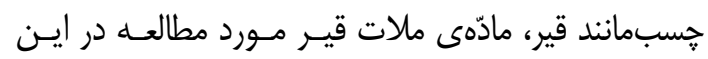

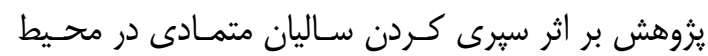

جدول ז: نتايج آزمايش XRD ملات قير تل آجرى

\begin{tabular}{ll}
\hline Calcite & $\mathrm{CaCO} 3$ \\
Anhydrite & $\mathrm{CaSO} 4$ \\
Feldespar & $(\mathrm{Ca})$ \\
Quartz & $\mathrm{SiO} 2$ \\
Dolomite & $\mathrm{CaMg}(\mathrm{CO} 3)$ \\
\hline
\end{tabular}

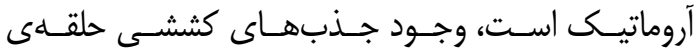

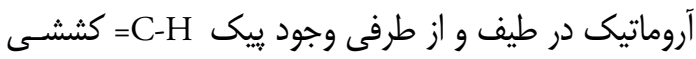

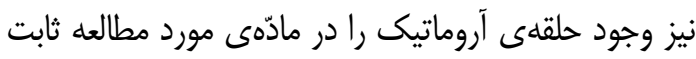

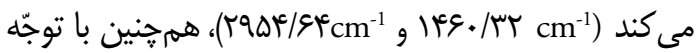

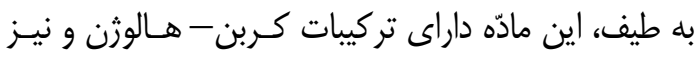

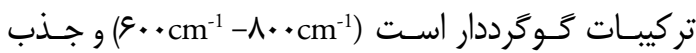
قوى در حدود

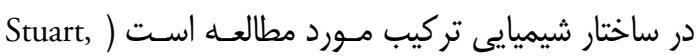

.2004

\section{צ- آزمايش هاى يراش و فلورسانس یرتو ايكس}

براى شناسايى بخش معدنى ملات قير، روشهاى تجزيــــ

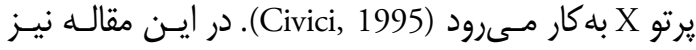

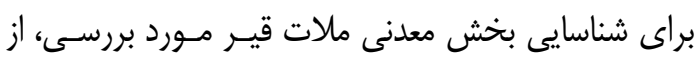
روشهاى طيفسنجى يراش و فلورسانس يرتو X استفاده

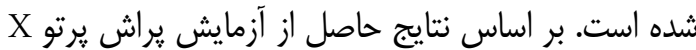

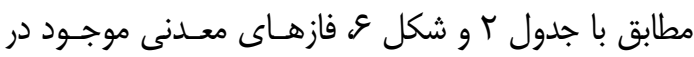
اين مادّه عبارتاند از: كلسيت، انيدريت، فلدسبار (كلسـيهم)،

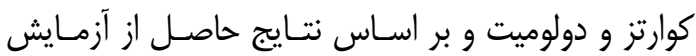

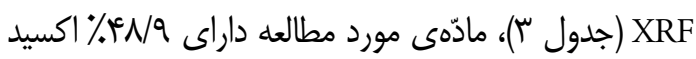

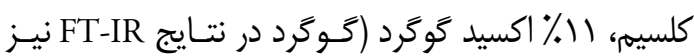

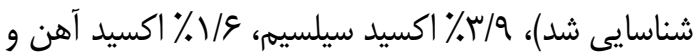
ه/ \$ اكسيد منيزيم است و درصد مواد آلى از بين رفتـهـ V L.O.I محاسبهى درصد بخشهاى آلى و معـدنى در مخلـوط در

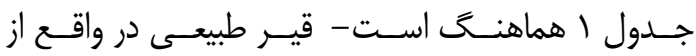
كانىهاى نفتى است كه در ساختار شيميايى معدنى آن در

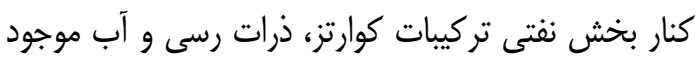

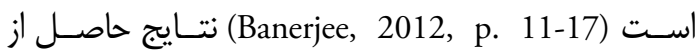

جدول س: :تايج آزمايش XRF ملات قير تل آجرى

\begin{tabular}{|c|c|c|c|c|c|c|c|}
\hline تركيب & درصد وزنى & تركيب & درصد وزنى & تركيب & درصد وزنى & تركيب & درصد وزنى \\
\hline $\mathrm{MgO}$ & 1.5 & $\mathrm{Al} 2 \mathrm{O} 3$ & 1.0 & $\mathrm{SiO} 2$ & 3.9 & $\mathrm{SO} 3$ & 11.0 \\
\hline $\mathrm{Cl}$ & 0.16 & $\mathrm{~K} 2 \mathrm{O}$ & 0.32 & $\mathrm{CaO}$ & 48.9 & $\mathrm{Fe} 2 \mathrm{O} 3$ & 1.6 \\
\hline $\mathrm{SrO}$ & 0.5 & L.O.I & 31.07 & $\mathrm{La} \& \mathrm{Lu}$ & $<1$ & - & - \\
\hline
\end{tabular}




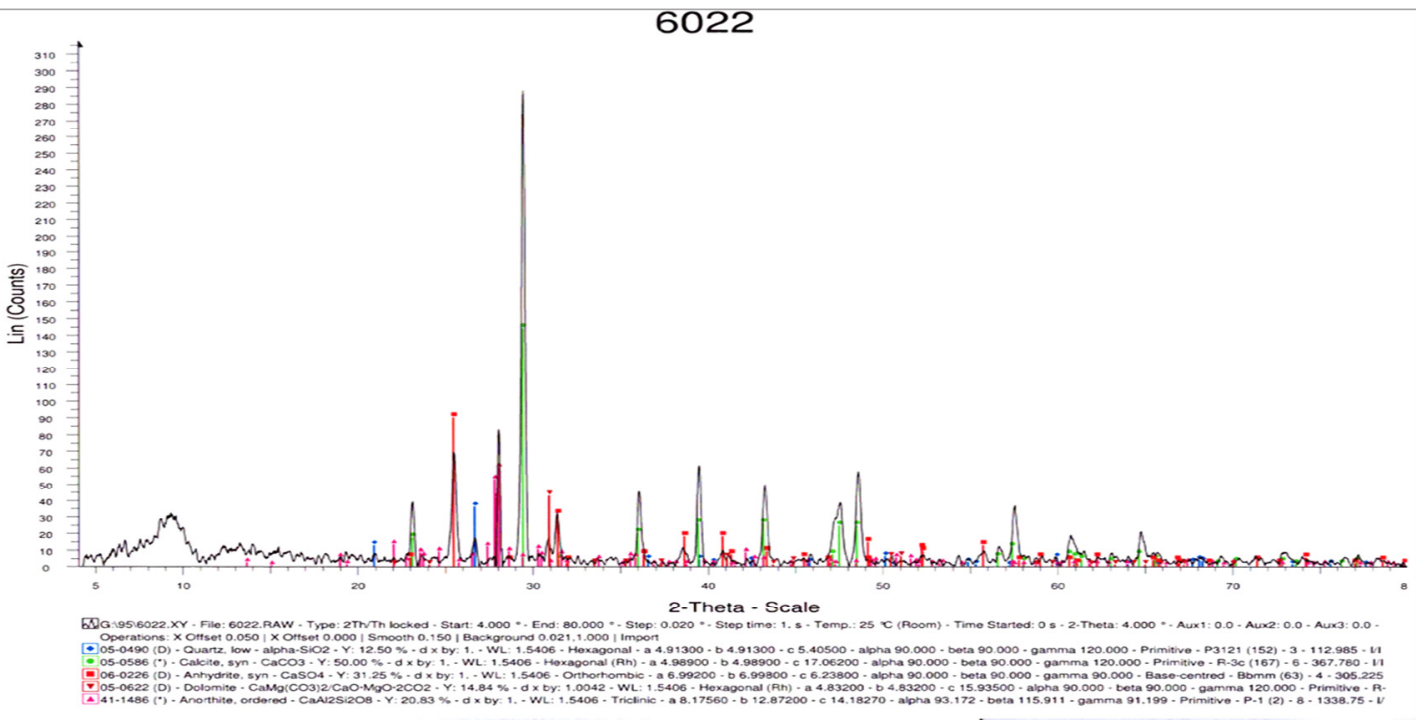

شكل \&: طيف نمونه ملات قير تل آجرى XRD

مولكولهاى بخش اشباع و روغـنهـا و رزيـنهـاى قيـر

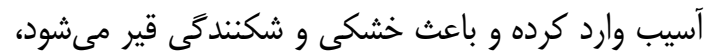

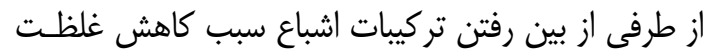

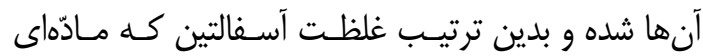
جامد و كلوئيدى است در تركيب قير افزايش مي يابـد كـهـ

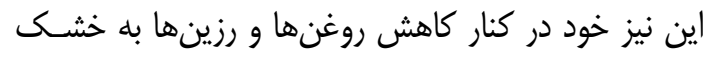

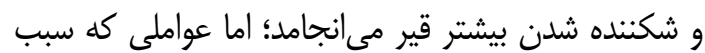

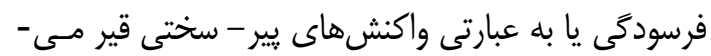

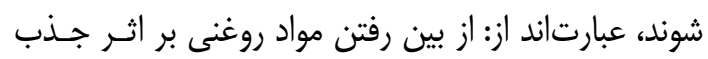

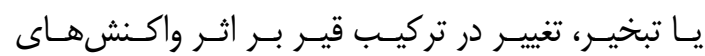

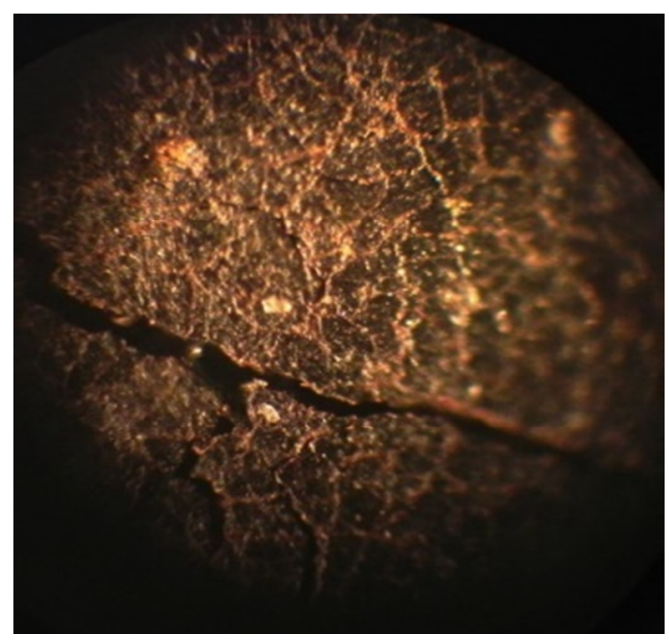

شكل Y: تصوير ميكروسكويى (100x) ملات قير و تركهاى روى آن آن

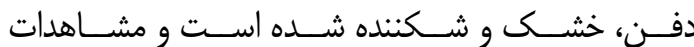

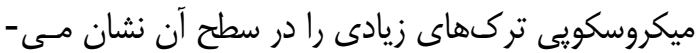
دهد (شكل V).

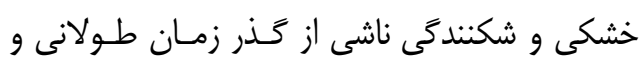
تغييرات در ساختار شيميايى قير است. تغييراتى كه مادّهاى

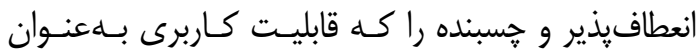
ملات را داشته بلهصورت خشكى و شـكنتدهى فعلى در آورده است كه بهراحتى از روى بدنهى آجر جدا مسى بــود. همانطور كه در بخش جداسازى نيز شرح داده شد ملات

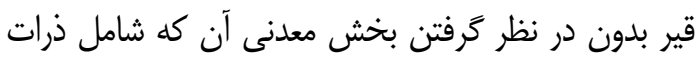

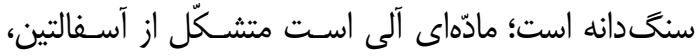

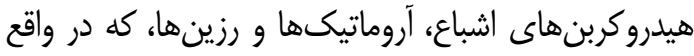

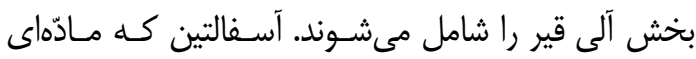

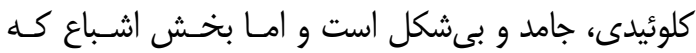
شامل روغنهاى معلنى با زنجيرههاى بلند هيدروكربنى و

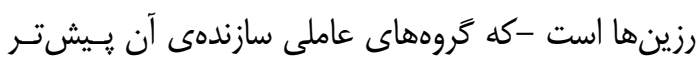
توسط روش FT-IR شناسـايى شـد-نقـــ اساسـى را در

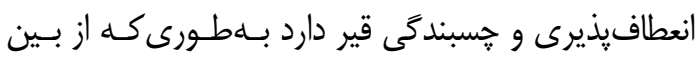
رفتن و تقليـل تركيبـات اشـباع در طـى سـاليان بـر اثـر ييشرفت فرآيندهاى فرسايش آسيب عمــده را بــه سـاختار

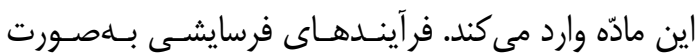

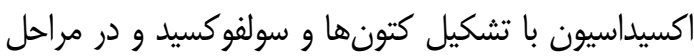

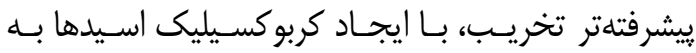

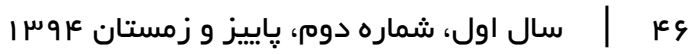


يادمان تل آجرى مخلوطى است از مواد هيدروكربنى كه

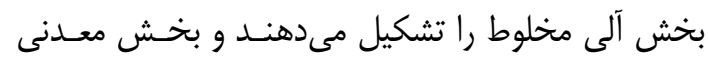

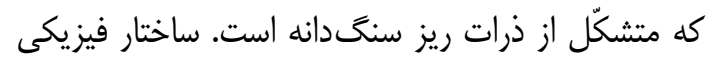

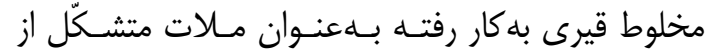

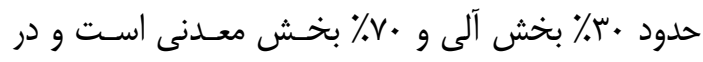

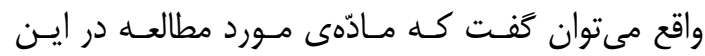
يزوهش ساختارى همانند آسفالت دارد. بـراى شناسـايى

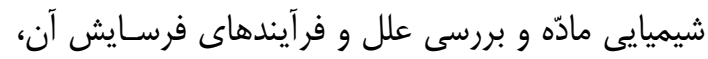
ملات قير به كمك روشهاى تجزيهى دستخاهى مـورد

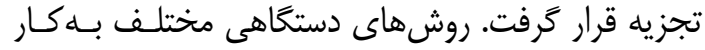

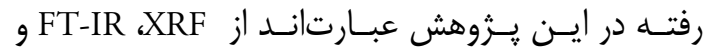
XRD نتايج بهدست آمده از ايـن دو آزمـايش حـاكى از آنساز وجود ذرات رسى و كوارتز در ساختار معدنى قير در كنـار

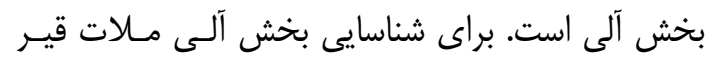

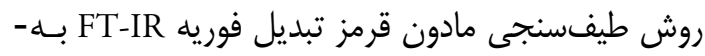
كار رفت و كروههاى عاملى ساختار شيميايى مادّه شامل مادي

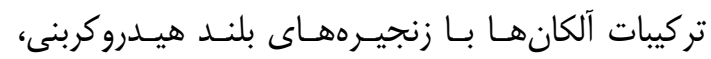

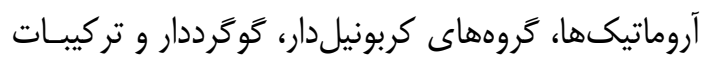
كربن-هالوزن شناسايى شدند. بر اساس نتايج حاصـل از

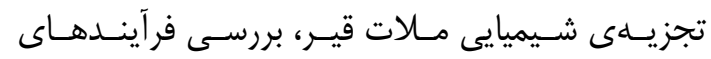

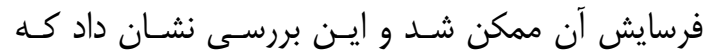

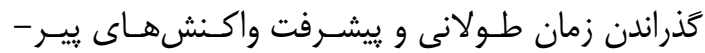

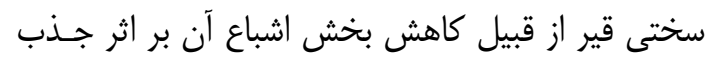

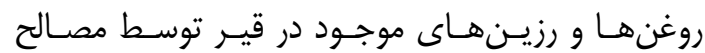
ساختمانى و از بين رفتن آنها به مرور زمان و در نتيجه

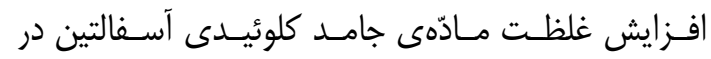
تركيب، همجنين واكنشهاى شيميايى بين تركيبات قير

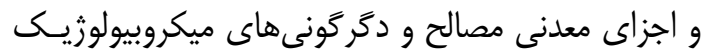
بر اثر فعاليتهاى زيستى ميكروار كانيسمها، سبب ايجـاد

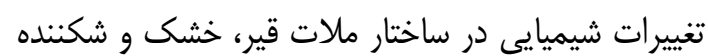

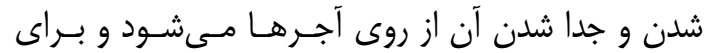

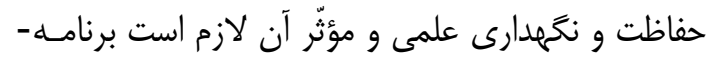
ريزى حفاظتى براى پايش محيطى دقيق صورت كيرد و بلويزه براى حفاظت آثار به كمك سقف مناسب از تابش

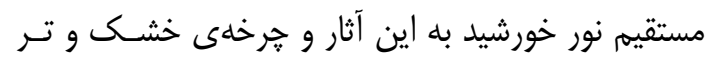

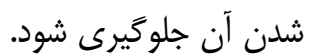

Peterson et ( اكسيداسيون و تغيير در ساختار مولكولى آن

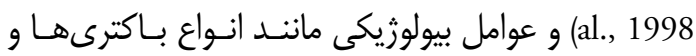

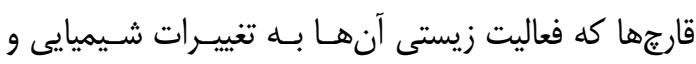
Ojeyemi, ) تخريب ساختار مولكولى قير طبيعى مى انجامانس

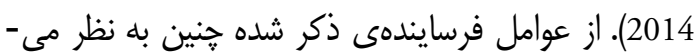
رسد كه با توجّه به ماهيت نمونههاى مورد مطالعه در ايسن

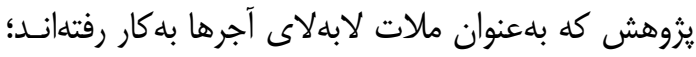
كزينههاى جذب روغن هاى موجود در قير توسط مصالح ساختمانى، كاهش غلظت بخش زنجيرههاى هيـدروكربنى

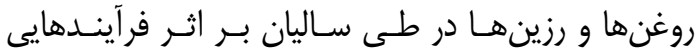

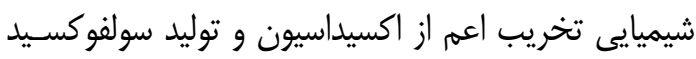

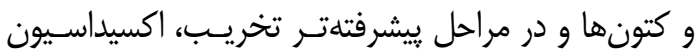
كروههاى كربونيل به كربو كسيليك اسـيدهـا در تركيبـات موجود در قير كه سـبب كاهش بخـش اشـباع قيــر و در

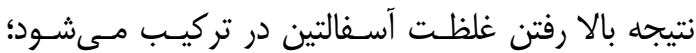

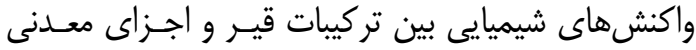

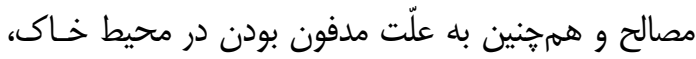
دَّرَونىهاى ميكروبيولوزيك بر اثر فعاليـت بيوشـيميايى

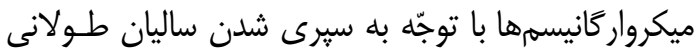
از زمان كاربرد قير طبيعى در ميان مصالح آجرى تـاكنون، بيشترين تأثير را در فرسايش و خشكى ائى اين مـادّه داشـته

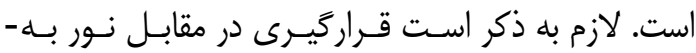
خصوص تابش فرابنفش نـور خورشـيد عـلاوه بــر ايجـاد خشكى و تغييرات فيزيكى مانند خرد شدن، مى تواند سبب نهاب

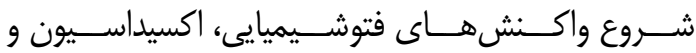
يليمريزاسيون شده و باعث آسيبهاى بيشترى در مـاتلات

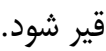

\section{1- 1 - 1تيجه كيرى}

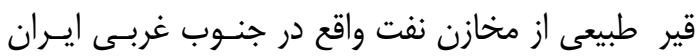

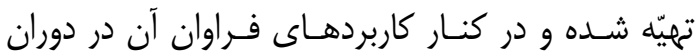
باستان، بهعنوان ملات ضدّ آب لابهلاى آجرها نيز براى دان دان دان دان

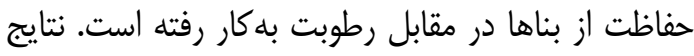

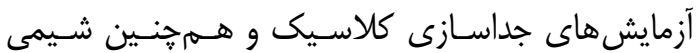
تجزيه دستخاهى در اين يزوهش نشان مىدهد كه قيـر

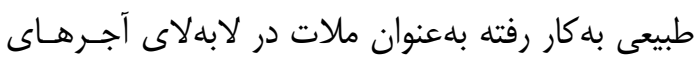




$$
\begin{aligned}
& \text { آزمايشكاهى در حفاظت و مرمت بناهاى تاريخى (مواد } \\
& \text { و مصالح). تهران: دانشخاه تهران. }
\end{aligned}
$$

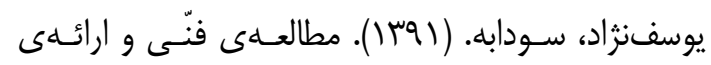

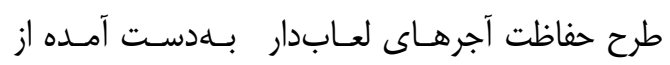

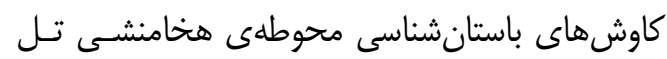

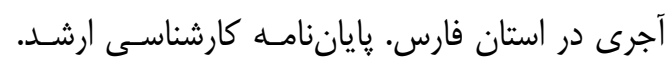

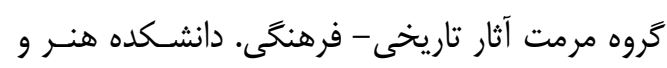

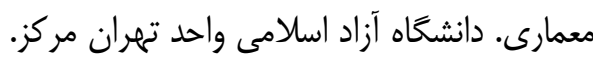

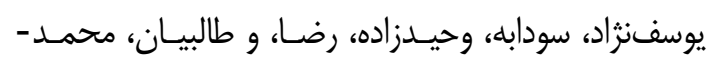

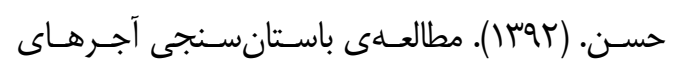

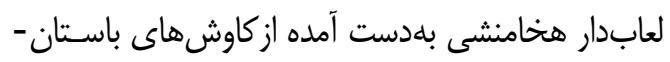

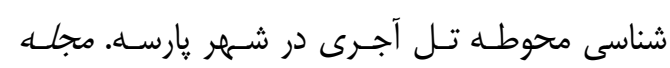

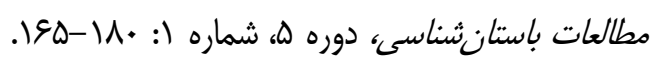

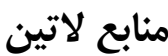

Banerjee, D. K. (2012). Oil Sands, Heavy Oil, \& Bitumen: From Recovery to Refinery. PennWell Corporation.

Borrego, A. G. (1996). 1H NMR and FTIR spectroscopy studies of bitumen and shale oil from selected Spanish oil shales. In Fuel and Energy Abstracts (Vol. 5, No. 37, p. 344).

Civici, N. (1995). Determination of vanadium and nickel in oil, asphaltene and bitumen using thinfilm energy-dispersive $x$-ray fluorescence spectrometry. X-Ray Spectrometry, 24(4), 163-166.

Connan, J. (1997). Le bitumen dans l'antique. conférence du 25. Bulletin de l' A.MI.S.

Connan, J., Kozbe, G., Kavak, O., Zumberge, J., \& Imbus, K. (2013). The bituminous mixtures of Kavuşan Höyük (SE Turkey) from the end of the 3rd millennium (2000BC) to the Medieval period (AD 14th century): Composition and origin. Organic geochemistry, 54, 2-18.

Connan, J., Nissenbaum, A., Imbus, K., Zumberge, J., \& Macko, S. (2006). Asphalt in iron age excavations from the Philistine Tel Miqne-Ekron city (Israel): Origin and trade routes. Organic geochemistry, 37(12), 1768-1786.

Largeau, C. (1996). Le bitumen à Suse (Bitumen at Susa): By J. Connan and O. Deschesne. Editions de la Réunion des Musées Nationaux, Paris. 1996. 444 pp. ISBN 2-7118-3092-6, FF 300.00.

Lewan, M. D., \& Maynard, J. B. (1982). Factors controlling enrichment of vanadium and nickel in the bitumen of organic sedimentary rocks. Geochimica et Cosmochimica Acta, 46(12), 2547-2560.

Marschner, R. F., Duffy, L. J., \& WRIGHT, H. T. (1978). Asphalts from ancient town sites in southwestern Iran. Paleorient, 97-112.

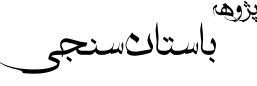

\author{
سباسگَزارى
}

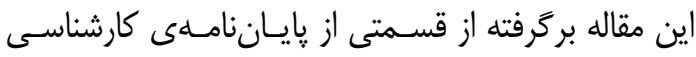

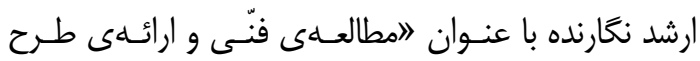

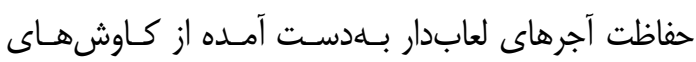

باستانشناسى محوطهى هخامنشى تل آجـرى در اسـتان

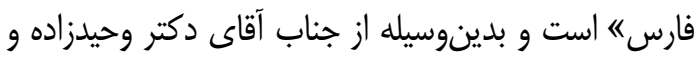
جناب آقاى دكتر طالبيان، مديريت محتـرم و كارشناسـان

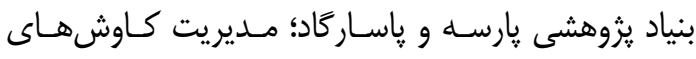

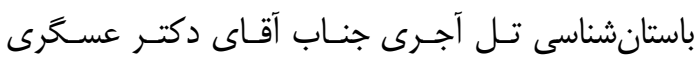

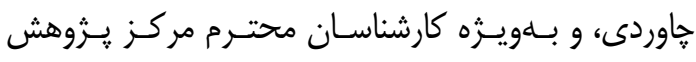

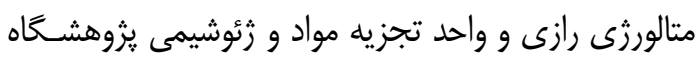

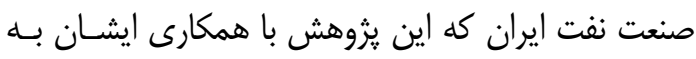
انجام رسيد تشكّر و قدردانى مى گرددد.

\section{منابع فارسى إنى}

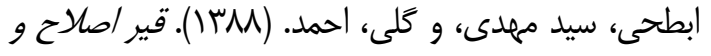
نكهيدارى. اصفهان: مؤسسه علمى دانشيثروهان.

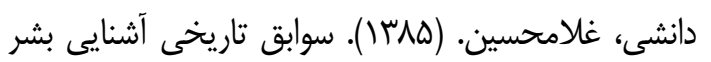
با نفت بر اساس يافتههاى باستانشناسان و نوشتهانها

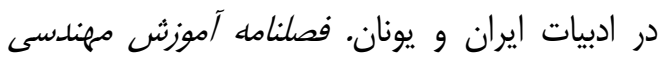

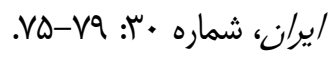

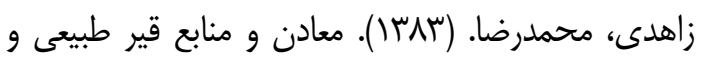
تجارت آن در خاور نزديك باستان بر اساس متون و و

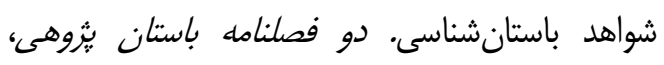

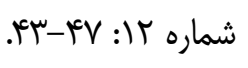

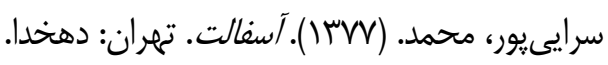

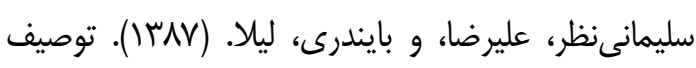

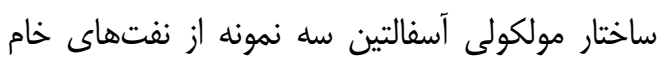

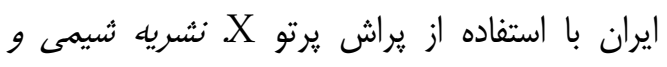

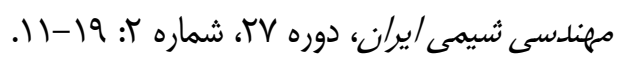

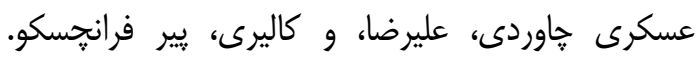

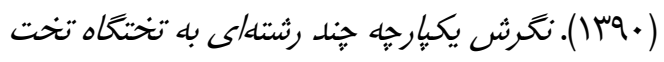

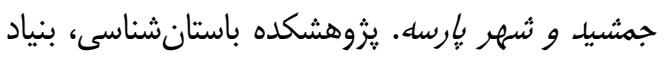

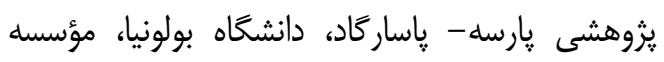
ايزمئو ايتاليا، (منتشر نشده).

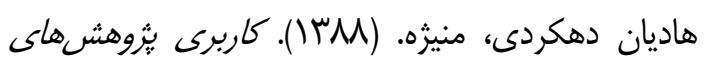


May, E., \& Jones, M. (2006). Conservation science: heritage materials. Royal Society of Chemistry.

Ojeyemi, M. O., Adediran, G. O., Adekola, F. A., Adelowo, O. O., \& Olajire, A. A. (2014). Biodegradation of hydrocarbon compounds in Aghabu natural bitumen. African journal of Biotechnology, 13(11), 1257-1264.

Reena, C., \& Kaur veinder, S. (2012). Characterization of bitumen and modified bitumen using FT-IR and SEM techniques. Research journal of chemical science, 2(8), 31-36.

Petersen, J., \& Harnsberger, P. (1998). Asphalt aging: dual oxidation mechanism and its interrelationships with asphalt composition and oxidative age hardening. Transportation Research Record: Journal of the Transportation Research Board, (1638), 47-55.

Schwartz, M., \& Hollander, D. (2000). Annealing, distilling, reheating and recycling: bitumen processing in the Ancient Near East. Paléorient,
83-91.

Stuart, Barbara H. (2004). Infrared Spectroscopy: Fundamentals and Applications. ANTS.

Traxller, R. N. (1967). Relation between asphalt composition and hardening volalitization and oxidation. Association of asphalt paving technologists 30, 359-377.

Wang, T., Zhang, C., Zhao, R., Zhu, C., Yang, C., \& Liu, C. (2014). Solvent Extraction of Bitumen from Oil Sands. Energy \& Fuels, 28(4), 2297-2304.

Wong, M. L., An, D., Caffrey, S. M., Soh, J., Dong, X., Sensen, C. W., ... \& Voordouw, G. (2015). Roles of Thermophiles and Fungi in Bitumen Degradation in Mostly Cold Oil Sands Outcrops. Applied and environmental microbiology, 81(19), 68256838.

Yoon, S., Son, J., Lee, W., Lee, H., \& Lee, C. W. (2009). Prediction of bitumen content in oil sand based on FT-IR measurement. Journal of Industrial and Engineering Chemistry, 15(3), 370-374. 